\title{
Imagination
}


Other Books by the Autbor

EXISTENTIALISM

(Oxford)

EXISTENTIALIST ETHICS

(Macmillan)

THE PHILOSOPHY OF SARTRE

(Hutcbinson)

ETHICS SINCE 1900

(Oxford) 


\title{
Imagination
}

\section{Mary Warnock}

\author{
따용
}

\section{สิด}

UNIVERSITY OF CALIFORNIA PRESS

Berkeley and Los Angeles 
University of California Press

Berkeley and Los Angeles, California

ISBN: 0-520-03724-3

Library of Congress Catalog Card Number: 75-22663

All rights reserved
( ) Mary Warnock 1976

First Paperback Printing 1978

Printed in the United States of America 